\title{
The Nexus Between Financial Development and Renewable Energy Consumption: A Review For Emerging Countries
}

OGUZ SAYGIN ( $\square$ osaygin@nevsehir.edu.tr)

Nevsehir Haci Bektas Veli Universitesi https://orcid.org/0000-0002-0272-5553

Ömer İskenderoğlu

Niğde Ömer Halisdemir Üniversitesi: Nigde Omer Halisdemir Universitesi

\section{Research Article}

Keywords: Financial Development, Renewable Energy Consumption, Renewable Energy Sources, Dynamic Panel Data Analysis, System GMM Method

Posted Date: May 10th, 2021

DOl: https://doi.org/10.21203/rs.3.rs-453220/v1

License: (c) (1) This work is licensed under a Creative Commons Attribution 4.0 International License.

Read Full License

Version of Record: A version of this preprint was published at Environmental Science and Pollution Research on October 6th, 2021. See the published version at https://doi.org/10.1007/s11356-021-166905 . 


\begin{abstract}
Asst. Prof. Dr. Oğuz SAYGIN Nevsehir H. B. V. University, Department of Accounting and Tax App., 2000 Evler 50300 Nevşehir-TURKEY. e-mail: osaygin@nevsehir.edu.tr https://orcid.org/0000-0002-0272-5553
\end{abstract}

Prof. Dr. Ömer İSKENDEROĞLU Niğde Ömer Halisdemir University, Department of Business, Main Campus 51240 Bor Yolu Üzeri, Niğde-TURKEY. e-mail:oiskenderoglu@ohu.edu.tr https://orcid.org/0000-0002-3407-1259

\begin{abstract}
The relationship between financial development and energy consumption is the most frequently research field in finance and economy. The main objective of carrying out this study is to answer that is there a relationship between financial development and renewable energy consumption in emerging countries? In many studies carried out in international literature, the empirical findings were pointing to the existence of this relationship. In order to examine the relationship between financial development and renewable energy consumption, a total of 20 emerging countries, benefited from annual frequency data between 1990 and 2015. The system GMM estimation was used as the method of study. As a result of the analysis performed indicates that financial development does not impact renewable energy consumption in emerging countries when financial development is measured using both banking and stock market variables. Additionally, it can be said that the financial development increases renewable energy consumption if it is measured by only stock market capitalization.
\end{abstract}

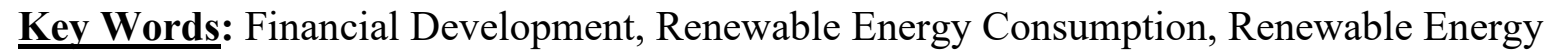
Sources, Dynamic Panel Data Analysis, System GMM Method.

\title{
Highlights
}

- This paper examines financial development and renewable energy consumption from 1990 to 2015 using system generalized method of moments (GMM) estimators.

- Financial development is measured both banking and stock market variables.

- There is no relationship between financial development and renewable energy consumption in emerging countries when financial development is measured using both banking and stock market variables. 
$45 *$ This paper is generated by the part of Ph.D dissertation. 


\section{Introduction}

The development of monetary and capital markets has great prospects for stabilization and the establishment of a financially stronger economic infrastructure. The main reason why financial development is so important for the countries is that it contributes to the economic growth of the country by directing the savings to investments effectively. Through an advanced financial system, both investors and entrepreneurs are offered the opportunity to diversify risk through a large number of different financial instruments and institutions. Thus, the country's savings opportunities are expanding and the capital required for economic growth is created. In order to achieve economic growth in a country, investments must be increased firstly. The way to make more investments is through increasing the savings, which are the source of the investments.

Another factor that is thought to be important for countries to attain the growth targets and financial development level they want to achieve in the long run is the energy policies of the countries. In the process of globalization, dependency levels of countries in the energy sector are altering day by day. Since energy is now more crucial not only as an input used in the industry but also it is the sector with almost the largest share of the total cash flow on the markets. Energy sources, which are such an indispensable factor for the economy, can be classified in many different ways. One of these classifications can be divided into renewable and non-renewable energy sources. At this point, what is meant by renewable energy is that, the same quality can be available the next day in the natural cycle process; in other words, they are inexhaustible energy sources, although they are used. Most of the increasing global energy demand is met by non-renewable energy sources, also known as fossil fuels. However, the limited availability of fossil fuels, particularly petroleum sources, has led all countries to take advantage of alternative energy sources. It is understood from these developments that renewable energy sources have an increasing importance.

The renewable energy sector has made some developments and trends in the last 20 years, although the prices of fossil fuels are in a downward trend. At the beginning of these developments, which are especially the decrease in the prices of solar and wind energy technologies and the more attention to the issue of energy storage. Despite the wide variations and decrease in growth rates among countries in the last 10 years, worldwide primary energy demand has increased by an average of $1.8 \%$ annually since 2011. Additionally, while developing countries saw growth in primary energy demand; on the contrary, there is a decrease in developed countries (Ren21, 2017). Although they encourage economic growth, especially in developing countries, they have difficulties in performing their efforts to protect environmental factors. The most crucial key of such decisions is a prediction of the social benefits of an improved environment (Alberini, 1997).

Apart from financial development, there are a wide range of studies examining the relation between renewable energy and other factors such as economic growth, income, wealth, oil prices and carbon 
dioxide emissions. This study fills the gap in the literature by concentrating on the renewable energy consumption in particular and examining separately both \% of total final energy consumption and a unit of measure in terajoule ( $\mathrm{tj}$ ) to measure renewable energy consumption. The aim of this paper is to determine whether there is a link between financial development and renewable energy consumption in emerging countries? Annual frequency data obtain for totally 20 emerging countries. Empirical models are constructed by operating system generalized method of moments (System-GMM) estimators with a strongly balanced data. The coming parts of the study presented the theoretical background, literature, empirical model and methodology, empirical results and conclusion.

\section{Theoretical Background}

Financial development, which broadly defined, the development of financial markets or the increase in the spread and diversity of securities traded in financial markets in the country. By means of financial development, the efficiency of the financial system increases and it contributes to the welfare of countries, leading to an increase in energy demand. It encourages countries, are financially developing, to reduce their borrowing costs, transparency in debt relations, ease of capital and investment transfer between countries, access to energy-saving products and technologies and ultimately, preferring efficient systems in the energy sector. These developments affect the energy demand by increasing the fixed investments and consumption in countries. Countries planning to increase the amount of renewable energy-based generation should invest in increasing the amount of such non-competitive technologies. If countries target to contribute more from the efficient side of renewable energy, it will be beneficial to have an incentive system that will encourage renewable energy investments. This incentive system should both support the implementation of new technologies based on renewable energy and make these technologies more competitive in the market (Savolainen and Svento, 2013).

Financial development can increase or decrease energy demand in different ways. Financial development allows more energy to be consumed in the country by providing convenience in satisfying the demands of individuals. On the other hand, when this effect is considered in terms of businesses; financial development encourages enterprises to increase their capacity and purchase more machinery and equipment, as it enables businesses to achieve the capitals quickly and have a more affordable cost for their fixed investments. In addition, businesses are provided the opportunity to access appropriate capitals to expand their activities by issuing stocks on stock markets. It contributes to the spread of capital by increasing the number of companies traded on stock markets of the country and enabling investors risk diversification. Thusly, the economic wealth of the country increases and confidence is established in the stock markets (Sadorsky, 2010).

The importance of the financial intermediary in an economy can hardly be overstated. One of the most important aspects of a financial intermediary is that it emerges to solve market failures by mitigating 
high information and transaction costs. Stieglitz and Weiss (1981) claim that market failures may

117 distort the market mechanism and thus lead to inefficient resource allocation. Inefficient resource

118 allocation, which is a result of high information and transaction costs, might slow down or stop

119 economic growth. Considering an economy without a financial intermediary, investor's face very high

120 costs in gathering, collecting, and processing information on companies in which they want to invest.

121 They might be better off not to make any investment, given that these costs might be higher than

122 expected net investment profits (Ampornpisit, 2011). These points are evaluated together; financial

123 development dynamics are of great importance for the capacity of investments to be made in every

124 sector in economies, especially the energy sector.

125 Renewable energy corresponding to the interpretation of the International Energy Agency IEA; it is

126 defined as sources that can be obtained by natural means and renewable as countless. Energy policies

127 of countries change with the effect of globalization process and energy is not only used as an input in

128 industrial field; it is also an important factor that can affect the price of a large number of commodities

129 with market volatility. This situation has increased the importance given to energy policies by the

130 countries' and has encouraged countries to develop regulatory and incentive policies to effectively

131 utilize renewable energy sources. In parallel with the technological conditions developing in every

132 sector in the world, the energy requirements of the countries are constantly increasing. Since the

1332000 s, the amount of energy required has been on an upward trend every year and it is thought that

134 this increase will reach higher dimensions in the coming years. For this reason, countries should turn

135 to renewable energy sources due to the environmental factors and to reach the energy potential needed

136 (Çakar et al, 2009). Renewable energy as a means to reduce the environmental impact of carbon

137 emissions while providing the power demands for economic growth, thus, in recent years, growing

138 recognition being presented to renewable energy, as a result analysis on the relation between

139 renewable energy consumption and economic growth has risen in the literature. Nonetheless, this

140 subsidiary is not as advanced as the early one and the total of reported researches is relatively limited

141 (Fang, 2011). Especially the link between finance and energy consumption turns out to be the most

142 precise to variations. This may be because monetary reforms are simpler and receive fewer time to

143 realize than economy wide constitutional reforms. Developers of financial reforms, notably in

144 countries where financial development leads to energy consumption should respect their impact on the

145 energy sector (Ciftci et al., 2020).

146 The relation between energy consumption and economic growth is the point of view in sustainable

147 development. That many countries signed on sustaining energy and lessening CO2 emissions has

148 raised the attractiveness of energy consumption associated studies. However, the mean dynamic in

149 those studies is the utilization of renewable energy sources. With the increasing attention of

150 sustainable development, researchers have excited further in the effects of renewable energy

151 consumption on economic growth and renewable energy sources have been observed as one of the 
most significant factors in the overall energy consumption of the World (Tuğcu et al., 2012). As of 2016, all countries directly supported renewable energy technology evolution and distribution through some mix of strategies. Decision makers proceeded to enforce policies during the period to engage investment, encourage deployment, foster innovation, and support stronger flexibility in energy infrastructure that holds enabling technologies such as energy storage. A wide variety of policies implemented direct and indirect support, targeted at economy-expanded industrial expansion, environmental conservation and public preservation. Technology storms, decreasing costs and increasing penetration of renewables in many regions still have proceeded to require that actions support to stimulate renewables formation and integration as productively as possible (Ren21, 2017).

\section{Literature Review}

To date, there has been a vast body of reported analysis examining the linkage between financial development and energy consumption (see, for example, the multi-country studies by, Mielnik and Goldemberg, 2002; Sadorsky, 2010; Sadorsky, 2011; Kakar et al., 2011; Shahbaz and Lean, 2012; Ozturk and Acaravc1, 2012; Çoban and Topçu, 2013; Lebe and Akbaş, 2015; Rafindadi and Öztürk, 2016). In these studies, the relationship between energy consumption and financial development have been examined such factors economic growth, international trade, carbon dioxide emissions, foreign direct investment and oil prices. Since 2000, many studies in the literature have included some variables for measuring renewable energy. Besides, out of the financial development factor, different factors such as economic growth, income, economic welfare, oil prices and renewable energy consumption relationship have also been examined in some other studies (see, for example, Payne, 2009; Sadorsky, 2009; Chang et al., 2009; Brunnschweiler, 2010; Apergis and Payne, 2010a; Apergis and Payne, 2010b; Apergis and Payne, 2011; Tuğcu et al., 2012; Apergis and Payne, 2012.

Although there is a considerable research examining into the relation between economic growth and financial development, there were limited research on the linkage between renewable energy consumption and financial development. One of the primary studies investigating the nexus between renewable energy and financial development generated by Brunnschweiler (2010). This research investigates the role of the financial sector in renewable energy development. It established the bias of financial sector development on the usage of renewable energy resources in panel estimations on up to 119 non-OECD countries for 1980-2006. Financial intermediation, in particular commercial banking, has a significant positive effect on the quantity of renewable energy supplied, and the effect is principally great as it was examined non-hydropower renewable energy such as wind, solar, geothermal and biomass. Fangmin and Jun (2011) in a review of top 55 global financial countries and regions, has directed the investigation to assess the significant effect from the financial intermediation sector to the evolution of the renewable energy sector in these regions during 1980-2008. This study has confirmed that there is a positive correlation between the expansion status of financial intermediation and the full energy production of the renewable energy projects in these regions, and 
this positive interaction in the energy production of the hydropower project is further clear. Zhang et al. (2011) examined the effect of China's stock market development on energy consumption between 1992-2009 with using the Grey relational analysis and Granger causality test. They found that the

191

192

193

194

195

196

197

198

199

200

201

202

203

204

205

206

207

208

209

210

211

212 Chinese stock market is associated with energy consumption in terms of both scale and efficiency. In Fang (2011) study, the position of both the extent and contribution of renewable energy consumption in monetary progress using Cobb-Douglas type production functions between 1978-2008 for China. This study has confirmed that renewable energy consumption and whose policies implemented have a positive effect on economic welfare.

In recent studies, Hassine and Harrathi (2017) examined the causal relation between renewable energy consumption, real GDP, trade and financial development for the Gulf Cooperation Council countries during the term 1980-2012. They found a unidirectional causality running from renewable energy consumption to private sector credit, which is assumed as the mediator of financial development. By dividing 19 Asia Cooperation Dialogue countries into three income groups, Ali et al. (2018) studied the transitions between financial development, tourism, trade sanitation, renewable energy and total reserves. The result of panel Granger causality under VECM produced evidence that financial development and renewable energy variables have a bidirectional link for small, middle and high income Asian countries. Ji and Zhang (2019) investigated how much financial development contributes to the renewable energy development in China. Results of this study indicate that financial development is critically important and contributes an overall of $42.42 \%$ to the variation of renewable energy growth. Eren et al. (2019) examined the effect of financial development and economic growth on renewable energy consumption in India over the duration 1971-2015. Follows of this research suggest statistically acceptable and positive impacts of economic growth and financial development on renewable energy consumption for the case of India. Some other studies are presented in table 1.

Table 1 - A summary of studies examining the nexus between renewable energy consumption, financial development and some other factors.

\begin{tabular}{|l|l|l|l|l|l|}
\hline \multicolumn{1}{|c|}{ Author(s) } & \multicolumn{1}{|c|}{ Variables } & \multicolumn{1}{c|}{ Method } & Duration & Countries & \multicolumn{1}{c|}{ Result } \\
\hline $\begin{array}{l}\text { Chien and Hu } \\
(2007)\end{array}$ & $\begin{array}{l}\text { Renewable energy and } \\
\text { macroeconomic } \\
\text { efficiency }\end{array}$ & $\begin{array}{l}\text { Data } \\
\text { envelopment } \\
\text { analysis }\end{array}$ & 2001-2002 & $\begin{array}{l}\text { Total 45 } \\
\text { countries }\end{array}$ & $\begin{array}{l}\text { Positive } \\
\text { relationship was } \\
\text { found. }\end{array}$ \\
\hline $\begin{array}{l}\text { Sadorsky } \\
(2009)\end{array}$ & $\begin{array}{l}\text { Income and Renewable } \\
\text { energy }\end{array}$ & $\begin{array}{l}\text { Panel } \\
\text { cointegration }\end{array}$ & $1994-2003$ & $\begin{array}{l}18 \text { Emerging } \\
\text { economy }\end{array}$ & $\begin{array}{l}\text { Positive } \\
\text { relationship was } \\
\text { found. }\end{array}$ \\
\hline $\begin{array}{l}\text { Chang et al. } \\
(2009)\end{array}$ & $\begin{array}{l}\text { Economic growth and } \\
\text { Renewable energy }\end{array}$ & $\begin{array}{l}\text { Threshold } \\
\text { effect }\end{array}$ & $1997-2006$ & $\begin{array}{l}\text { 30 OECD } \\
\text { Member } \\
\text { countries }\end{array}$ & $\begin{array}{l}\text { Positive } \\
\text { relationship was } \\
\text { found in countries } \\
\text { characterized by } \\
\text { high-economic } \\
\text { growth }\end{array}$ \\
\hline
\end{tabular}




\begin{tabular}{|c|c|c|c|c|c|}
\hline $\begin{array}{l}\text { Brunnschweil } \\
\text { er }(2010)\end{array}$ & $\begin{array}{l}\text { Financial development } \\
\text { and Renewable energy }\end{array}$ & Sistem GMM & $\begin{array}{l}1980- \\
2006\end{array}$ & $\begin{array}{l}119 \text { Non } \\
\text { OECD } \\
\text { Member } \\
\text { countries }\end{array}$ & $\begin{array}{l}\text { Positive } \\
\text { relationship was } \\
\text { found. }\end{array}$ \\
\hline $\begin{array}{l}\text { Apergis and } \\
\text { Payne (2010a) }\end{array}$ & $\begin{array}{l}\text { Economic growth and } \\
\text { Renewable energy }\end{array}$ & $\begin{array}{l}\text { Panel unit } \\
\text { root, } \\
\text { cointegration } \\
\text { and Granger } \\
\text { causality }\end{array}$ & $1985-2005$ & $\begin{array}{l}20 \text { OECD } \\
\text { Member } \\
\text { countries }\end{array}$ & $\begin{array}{l}\text { Positive } \\
\text { relationship was } \\
\text { found. }\end{array}$ \\
\hline $\begin{array}{l}\text { Apergis and } \\
\text { Payne } \\
(2010 \mathrm{~b})\end{array}$ & $\begin{array}{l}\text { Economic growth and } \\
\text { Renewable energy }\end{array}$ & $\begin{array}{l}\text { Panel unit } \\
\text { root, } \\
\text { cointegration } \\
\text { and Granger } \\
\text { causality }\end{array}$ & $1992-2007$ & $\begin{array}{l}13 \text { Eurasian } \\
\text { countries }\end{array}$ & $\begin{array}{l}\text { Positive } \\
\text { relationship was } \\
\text { found. }\end{array}$ \\
\hline $\begin{array}{l}\text { Fangmin and } \\
\text { Jun (2011) }\end{array}$ & $\begin{array}{l}\text { Financial development } \\
\text { and Renewable energy }\end{array}$ & $\begin{array}{l}\text { Panel fixed } \\
\text { and random } \\
\text { effects }\end{array}$ & 1980-2008 & 55 Countries & $\begin{array}{l}\text { Positive } \\
\text { relationship was } \\
\text { found. }\end{array}$ \\
\hline $\begin{array}{l}\text { Zhang et al. } \\
\text { (2011) }\end{array}$ & $\begin{array}{l}\text { Stock market } \\
\text { development and } \\
\text { energy consumption }\end{array}$ & $\begin{array}{l}\text { The Grey } \\
\text { Relational } \\
\text { Analysis and } \\
\text { Granger } \\
\text { causality }\end{array}$ & 1992-2009 & China & $\begin{array}{l}\text { Positive } \\
\text { relationship was } \\
\text { found. }\end{array}$ \\
\hline Fang (2011) & $\begin{array}{l}\text { Economic welfare and } \\
\text { Renewable energy }\end{array}$ & $\begin{array}{l}\text { Cobb-Douglas } \\
\text { type } \\
\text { production } \\
\text { functions }\end{array}$ & $1978-2008$ & China & $\begin{array}{l}\text { Positive } \\
\text { relationship was } \\
\text { found. }\end{array}$ \\
\hline $\begin{array}{l}\text { Apergis and } \\
\text { Payne (2011a) }\end{array}$ & $\begin{array}{l}\text { Economic growth and } \\
\text { Renewable energy }\end{array}$ & $\begin{array}{l}\text { Panel unit } \\
\text { root, } \\
\text { cointegration, } \\
\text { Granger } \\
\text { causality and } \\
\text { Error } \\
\text { correction } \\
\text { model }\end{array}$ & $1980-2006$ & $\begin{array}{l}6 \text { States of } \\
\text { America }\end{array}$ & $\begin{array}{l}\text { Positive } \\
\text { relationship was } \\
\text { found. }\end{array}$ \\
\hline $\begin{array}{l}\text { Apergis and } \\
\text { Payne } \\
(2011 b)\end{array}$ & $\begin{array}{l}\text { Economic growth and } \\
\text { Renewable energy }\end{array}$ & $\begin{array}{l}\text { Panel unit } \\
\text { root, } \\
\text { cointegration, } \\
\text { Granger } \\
\text { causality and } \\
\text { Error } \\
\text { correction } \\
\text { model } \\
\end{array}$ & 1990-2007 & $\begin{array}{l}\text { Developed } \\
\text { and } \\
\text { Emerging } \\
\text { countries }\end{array}$ & $\begin{array}{l}\text { Nonlinear causality } \\
\text { was found. }\end{array}$ \\
\hline $\begin{array}{l}\text { Tuğcu and } \\
\text { diğg. (2012) }\end{array}$ & $\begin{array}{l}\text { Economic growth and } \\
\text { Renewable energy }\end{array}$ & $\begin{array}{l}\text { Auto } \\
\text { Regressiand } \\
\text { Distributed } \\
\text { Lag (ARDL) } \\
\text { and } \\
\text { Hatemi-J } \\
\text { causality tests }\end{array}$ & 1980-2009 & $\begin{array}{l}\text { G7 } \\
\text { Countries }\end{array}$ & $\begin{array}{l}\text { Positive } \\
\text { relationship was } \\
\text { found. }\end{array}$ \\
\hline $\begin{array}{l}\text { Apergis and } \\
\text { Payne (2012) }\end{array}$ & $\begin{array}{l}\text { Economic growth and } \\
\text { Renewable energy }\end{array}$ & $\begin{array}{l}\text { Panel unit } \\
\text { root, } \\
\text { cointegration, } \\
\text { Granger } \\
\text { causality and } \\
\text { Error } \\
\text { correction } \\
\text { model }\end{array}$ & $1990-2007$ & 80 Countries & $\begin{array}{l}\text { Bidirectional } \\
\text { causality was } \\
\text { found. }\end{array}$ \\
\hline
\end{tabular}




\begin{tabular}{|l|l|l|l|l|l|}
\hline $\begin{array}{l}\text { Jebli et al. } \\
(2014)\end{array}$ & $\begin{array}{l}\text { Renewable energy, } \\
\text { CO2, tourism, } \\
\text { economic growth and } \\
\text { trade }\end{array}$ & $\begin{array}{l}\text { ARDL, } \\
\text { FMOLS, } \\
\text { DOLS }\end{array}$ & 1995-2010 & $\begin{array}{l}\text { Central and } \\
\text { South } \\
\text { America }\end{array}$ & $\begin{array}{l}\text { Bidirectional } \\
\text { causality was } \\
\text { found. }\end{array}$ \\
\hline $\begin{array}{l}\text { Hassine and } \\
\text { Harrathi } \\
(2017)\end{array}$ & $\begin{array}{l}\text { Renewable energy } \\
\text { consumption, real } \\
\text { GDP, trade and } \\
\text { financial development }\end{array}$ & $\begin{array}{l}\text { VECM, } \\
\text { FMOLS, } \\
\text { DOLS }\end{array}$ & $1980-2012$ & $\begin{array}{l}\text { The Gulf } \\
\text { Cooperation } \\
\text { Council } \\
\text { countries }\end{array}$ & $\begin{array}{l}\text { Unidirectional } \\
\text { causality was } \\
\text { found. }\end{array}$ \\
\hline $\begin{array}{l}\text { Ali et al. } \\
(2018)\end{array}$ & $\begin{array}{l}\text { Financial development, } \\
\text { tourism, trade } \\
\text { sanitation, renewable } \\
\text { energy and total } \\
\text { reserves }\end{array}$ & $\begin{array}{l}\text { VECM, } \\
\text { FMOLS }\end{array}$ & $1995-2015$ & $\begin{array}{l}\text { 19 Asia } \\
\text { Cooperation } \\
\text { Dialogue } \\
\text { ACD) } \\
\text { countries }\end{array}$ & $\begin{array}{l}\text { Bidirectional } \\
\text { causality was } \\
\text { found. }\end{array}$ \\
\hline $\begin{array}{l}\text { Eren et al. } \\
(2019)\end{array}$ & $\begin{array}{l}\text { Financial development, } \\
\text { Economic growth and } \\
\text { Renewable energy }\end{array}$ & $\begin{array}{l}\text { VECM, } \\
\text { DOLS }\end{array}$ & $1971-2015$ & India & $\begin{array}{l}\text { Unidirectional } \\
\text { causality was } \\
\text { found. }\end{array}$ \\
\hline $\begin{array}{l}\text { Chiu and Lee } \\
(2020)\end{array}$ & $\begin{array}{l}\text { Financial development } \\
\text { and Energy } \\
\text { consumption }\end{array}$ & $\begin{array}{l}\text { Panel smooth } \\
\text { transition } \\
\text { regression }\end{array}$ & $1984-2015$ & 79 Countries & $\begin{array}{l}\text { Positive } \\
\text { relationship was } \\
\text { found. }\end{array}$ \\
\hline
\end{tabular}

\section{Model, Data and Methodology}

\subsection{Model, Data}

In this study, we examine the dynamic relationships between financial development and renewable energy consumption during the period 1990-2015 handling system-GMM model with a strongly stabilized data for 20 emerging countries. Following Sadorsky (2010), the empirical models are established as a scaled down design dynamic panel model of renewable energy consumption. In Eq. (1), renewable energy consumption as $\%$ of total final energy consumption $\left(\mathrm{re}_{\mathrm{it}}\right)$ is described as a function of banking variables $\left(\mathrm{bv}_{\mathrm{it}}\right)$ and market variables ( $\left.\mathrm{mv}_{\mathrm{it}}\right)$. In Eq.(2), renewable energy consumption in terajoule (ret $\left.j_{i t}\right)$ is described as a function of banking variables $\left(b_{i t}\right)$ and market variables $\left(\mathrm{mv}_{\mathrm{it}}\right)$.

$r e_{i, t}=\alpha+\beta_{1} r e_{i, t-1}+\beta_{2} b v_{i, t}+\beta_{3} m v_{i, t}+\varepsilon_{i, t}$

$\operatorname{retj}_{i, t}=\alpha+\beta_{1} \operatorname{retj}_{i, t-1}+\beta_{2} b v_{i, t}+\beta_{3} m v_{i, t}+\varepsilon_{i, t}$

$\varepsilon_{i, t}=\mu_{i}+\vartheta_{i t}$

In models, $t$ indicates the time period $(t=1990, \ldots 2015)$ and $i$ indicates the country $(i=1, \ldots, 20)$. The

232 period between 1990 and 2015 was chosen as the period of analysis of the study, since significant 233 reductions in the number of countries that can be reached in the period prior to 1990 and for all 
countries to be reached by 2015 . While we are performing the study, we apply the system GMM approach to estimate the models. Lagged renewable energy consumption is considered as endogenous in the estimations of Eq. (1) and Eq. (2), regarding the relationships between each other. While the models are tested with the system GMM method, 9 different models were constructed by adding different independent variables from banking and market variables to the models for each dependent variable. Considering two different dependent variables, total of 18 different models, 9 models for each dependent variable, were tested separately for emerging countries.

İn this paper we use annual data on financial development and renewable energy consumption for 20 emerging countries, as reported in Morgan Stanley Capital International (MSCl) Emerging Markets Index (www.mscibarra.com). The condition of emerging markets is applied to specify according to the market capitalization. In accordance with the period of study, there are 20 emerging countries in the world. These countries are Brazil, Chile, China, Colombia, Czech Republic, Egypt, Greece, Hungary, India, Indonesia, Korea, Malaysia, Mexico, Peru, Philippines, Poland, Russia, South Africa, Thailand and Turkey.

Two different dependent variables were used in models to measure renewable energy consumption in the study. The data of renewable energy consumption (re) is measured as a share of total final energy consumption; renewable energy consumption (retj) is measured in terajoule. It is understood from the variables that the first variable is percentage and the second is the terajoule as a unit. We divide financial development variables into two main parts: banking variables and stock market variables as marked out in the previous studies. Considering Çoban and Topçu (2013), three banking variables and three stock market variables are determined as financial development variables. The banking variables used in the study are deposit money banks' assets to GDP (dbagdp), liquid liabilities to GDP (llgdp) and private credit by deposit money banks to GDP (pcrdbgdp). Besides, the stock market variables used in the study are stock market capitalization to GDP (stmktcap), stock market value traded to GDP (stvaltraded) and stock market turnover ratio (stturnover). The ratio of deposit money bank assets to GDP is an extensively employed financial development variable (Beck et al., 2000). All variables are in a logarithmic set in identified models. Banking and stock market variables are also modified to logarithmic form after index values are taken. It presents details of the variables employed in the study in table 2. 
Table 2 -Variables employed in the panel data analysis

\begin{tabular}{|c|c|c|c|c|}
\hline Variable Group & Variable Name & Abbreviation & Frequency & Source \\
\hline \multirow{2}{*}{$\begin{array}{l}\text { Renewable } \\
\text { Energy } \\
\text { Consumption } \\
\text { Variables }\end{array}$} & $\begin{array}{l}\text { Renewable energy } \\
\text { consumption }(\% \text { of total final } \\
\text { energy consumption) }\end{array}$ & re & $1990-2015$ & \multirow{2}{*}{$\begin{array}{l}\text { World Bank World } \\
\text { Development } \\
\text { Indicators (WDI) } \\
\text { database }\end{array}$} \\
\hline & $\begin{array}{l}\text { Renewable energy } \\
\text { consumption (TJ) }\end{array}$ & retj & $1990-2015$ & \\
\hline \multirow{3}{*}{$\begin{array}{l}\text { Banking } \\
\text { Variables }\end{array}$} & $\begin{array}{l}\text { Deposit money banks' assets to } \\
\text { GDP (\%) }\end{array}$ & dbagdp & $1990-2015$ & \multirow{6}{*}{$\begin{array}{l}\text { World Bank Global } \\
\text { Financial } \\
\text { Development } \\
\text { Database }\end{array}$} \\
\hline & Liquid liabilities to GDP (\%) & llgdp & $1990-2015$ & \\
\hline & $\begin{array}{l}\text { Private credit by deposit money } \\
\text { banks to GDP (\%) }\end{array}$ & pcrdbgdp & $1990-2015$ & \\
\hline \multirow{3}{*}{$\begin{array}{l}\text { Stock Market } \\
\text { Variables }\end{array}$} & $\begin{array}{l}\text { Stock market capitalization to } \\
\text { GDP }(\%)\end{array}$ & stmktcap & $1990-2015$ & \\
\hline & $\begin{array}{l}\text { Stock market total value traded } \\
\text { to GDP }(\%)\end{array}$ & stvaltraded & $1990-2015$ & \\
\hline & $\begin{array}{l}\text { Stock market turnover ratio } \\
(\%)\end{array}$ & stturnover & $1990-2015$ & \\
\hline
\end{tabular}

269 Descriptive statistics of the data are given in table 3.It is seen that the standard deviation of retj is very 270 high because this dependent variable is the terajoule as a unit not the percentage. It can be said that re dependent variable is more stable in terms of mean and standard deviation values than retj. Also, it is seen that the average values of financial development variables are close to each other. It is also observed that market variables are more changeable than banking variables.

274 Table 3 - Descriptive statistics

\begin{tabular}{|l|r|r|r|r|r|}
\hline Variable & \multicolumn{1}{l|}{ Obs } & Mean & $\begin{array}{l}\text { Std. } \\
\text { Dev. }\end{array}$ & Min & Max \\
\hline re & 520 & 1,1466 & 0,4419 & $-0,3550$ & 1,7682 \\
\hline retj & 520 & 5,5214 & 0,6780 & 4,1706 & 7,0806 \\
\hline dbagdp & 513 & 1,7286 & 0,2416 & 0,7844 & 2,2391 \\
\hline Ilgdp & 511 & 1,6890 & 0,2387 & 0,9849 & 2,2735 \\
\hline pcrdbgdp & 513 & 1,6051 & 0,2930 & 0,5172 & 2,2197 \\
\hline stmktcap & 505 & 1,5106 & 0,4799 & $-1,9051$ & 2,4242 \\
\hline stvaltraded & 506 & 1,0722 & 0,5820 & $-1,1460$ & 2,3627 \\
\hline stturnover & 504 & 1,5863 & 0,4350 & 0,1998 & 2,7458 \\
\hline
\end{tabular}

276 Table 4 is presented the correlations between the panel data variables. It is seen that the dependent 277 variables of the study are highly correlated between re and retj. Notice that banking variables and stock market variables are moderately remarkably interacted with each other and it was thought that it 
would be more convenient to include three banking and stock market variables into the models separately.

Table 4 - Correlations for the panel data set

\begin{tabular}{|c|c|c|c|c|c|c|c|c|}
\hline \multirow{3}{*}{ Variables } & \multirow{2}{*}{\multicolumn{2}{|c|}{$\begin{array}{c}\text { Dependent } \\
\text { Variables }\end{array}$}} & \multicolumn{6}{|c|}{ Independent Variables } \\
\hline & & & \multicolumn{3}{|c|}{ Banking Variables } & \multicolumn{3}{|c|}{ Stock Market Variables } \\
\hline & re & retj & dbagdp & llgdp & pcrdbgdp & stmktcap & stvaltraded & stturnover \\
\hline re & 1,0000 & & & & & & & \\
\hline retj & 0,6544 & 1,0000 & & & & & & \\
\hline dbagdp & $-0,1564$ & 0,0231 & 1,0000 & & & & & \\
\hline Ilgdp & $-0,1435$ & 0,0636 & 0,8742 & 1,0000 & & & & \\
\hline pcrdbgdp & $-0,1370$ & 0,0092 & 0,9347 & 0,7873 & 1,0000 & & & \\
\hline stmktcap & 0,0211 & 0,0466 & 0,4871 & 0,3458 & 0,5440 & 1,0000 & & \\
\hline stvaltraded & $-0,2074$ & 0,1318 & 0,5968 & 0,5052 & 0,6020 & 0,7104 & 1,0000 & \\
\hline stturnover & $-0,2464$ & 0,2293 & 0,2504 & 0,2944 & 0,1956 & $-0,0905$ & 0,5551 & 1,0000 \\
\hline
\end{tabular}

obs $=499$.

\subsection{Methodology}

In this study, dynamic panel data analysis method, which models the lagged values of variables as explanatory factor, is preferred in examining the relationship between financial development and renewable energy consumption. In addition, the presence of more than one country in the scope of the analysis is one of the reasons for applying this method. Dynamic panel data estimation is better convenient in processes. Some unobservable factors influence both the dependent variable and the explanatory variables in these processes. Also, some explanatory variables are heavily influenced to previous values of the dependent variable. This is supposed to be the matter in regressions of financial development on energy consumption (Çoban and Topçu, 2013). Finding out the channel between financial development and renewable energy consumption and in this respect assessing the variations of the financial sector in the emerging countries require convenient measures of financial development (Levine, 2005).

Arellano and Bond (1991) in their quest to contribute to the existing literature on the weaknesses of the fixed effects model, they introduced alternative method of estimation which removed time invariant effect $\alpha i$ from the regression after taking first difference as indicated in the model can be highlighted below;

$$
y_{i t}-y_{i t-1}=\gamma\left(y_{i t-1}-y_{i t-2}\right)+\left(x_{i t}-x_{i t-1}\right) \beta+\left(\mu_{i t}-\mu_{i t-1}\right)
$$

or

$$
\Delta y_{i t}=\gamma \Delta y_{i t-1}+\Delta x_{i t} \beta+\Delta \mu_{i t}
$$

The lagged error term $\mu_{i t-1}$ relies on $y_{i t-1}$ in the model above; hence this shows that ordinary least square (OLS) estimator of the model is not consistent. Therefore, an instrument matrix is needed with 
a view to break the correlation nature of the variables. Arellano and Bond (1991) recommend that; the optimal instrument will not depend upon any variables before determining whether the variables are predetermined or strictly exogenous. In this case, $x_{i t}$ are strictly exogenous and their moment conditions are:

$$
E=\left[x_{i s}\left(\mu_{i t}-\mu_{i t-1}\right)\right]=0_{p x 1} t=2, \ldots, T, \quad s=1, \ldots, T, \quad I=1, \ldots, N
$$

Arellano and Bover (1995) introduced new estimator known as system GMM with a view to resolve the weaknesses of the difference GMM estimator. Based on this estimator they argues that if the first condition $x i 1$ accomplishes the stationarity constraints $\mathrm{E}\left(\Delta x_{i} 2 \mu_{i}\right)=0$, then $\Delta x_{i t}$ is expected to be correlated with $\mu_{i t}$ only in a situation in which $\Delta x_{i 2}$ is correlated with $\mu_{i}$. The authors argue that, the existence of correlation between the level of the regressors $x_{i t}$ and unobserved individual specific effect $\mu_{i}$, there is no correlation between the differences of the regressors $\Delta x_{i t}$ and unobservable specific effect $\mu_{\mathrm{i}}$. The present assumption sets up the level equation estimator which employs other moment conditions. Lagged differences of right hand side variables $\Delta x i, \mathrm{t}-\mathrm{r}$ are employed as further instruments for equation in levels when $x i 1$ is mean stationary.

Blundell and Bond (1998) on the other hand, pointed out that lagged differences of the dependent variable simultaneously with the lagged differences of independent variable are appropriate instruments for the regression in the level equation with the initial conditions $y_{i t}$ accomplishes the stationary restraints $\mathrm{E}\left(\Delta y_{i} 2 \mu_{i}\right)=0$. Therefore, in a situation whereby $\Delta x_{i t}$ and $\Delta y_{i t}$ are not correlated with $\mu_{i 1}$, lagged differences of independent variable $\Delta x_{i t-r}$ together with the lagged differences of dependent variable $\Delta y_{i t-r}$ are efficient instruments for the level equations. Furthermore, Blundell and Bond (1998) revealed that, what is using to estimate system-GMM is the difference equation together with the moment conditions for level equation. If explanatory variables are measured and regarded exogenous the system-GMM estimator develops the below moment conditions:

$E\left(\Delta \varepsilon_{i t} y_{i t-r}\right)=0 ; E\left(\Delta \varepsilon_{i t} x_{i t-r}\right)=0$

Where $r=2, . ., t-1$, and $t=3, \ldots \ldots \ldots, T$

$E\left(\mu_{i t} y_{i t-r}\right)=0 ; E\left(\mu_{i t} x_{i t-r}\right)=0$

Where $r=1$, and $t=3, \ldots \ldots, T$,

The estimator of system-GMM combined different equations which includes; T-2 in difference and T2 of in the levels form combine both a single equation. Lagged levels of regressor and regressors are 
employed as instruments for the differenced equation and the lagged differences of regressor and regressors as instruments for the level equation. The estimator of system-GMM provide consistent and more efficient result parameter estimates and at the same time possess a better asymptotic and finite sample properties as presumed by Blundell and Bond (1998).

Dynamic models have unobserved country-level effects, which by structure are interacted with the lagged dependent variable, establishing standard estimators inconsistent. The Arellano and Bond (1991) first-differenced GMM estimator is logical for the criteria of this model, even though it even involves that there be no second-order serial autocorrelation in the idiosyncratic errors (Brunnschweiler, 2010). In addition, Ahn and Schmidt (1995) derived nonlinear additional moment constraints not included in GMM estimator of the Arellano and Bond (1991). System GMM approach first discussed in the study of Arellano and Bover (1995) and later Blundell and Bond (1998) provided a major recovery in dynamic panel data estimation methods.

Blundell and Bond (1998), when $\mathrm{N}>\mathrm{T}, \mathrm{N}$ is the section and $\mathrm{T}$ is the time dimension, the extra moment condition is taken into consideration in producing the effective instrumental variable estimator of the dynamic panel data model. In this study involved two different estimators approach for the model which could increase the sensitivity of the standard first-differenced GMM estimator. In the first approach, a linear GMM estimator is run in a system of first difference and level equations under all available moment conditions, introducing an additional constraint on the initial conditions. In the second approach, it is stated that under certain conditions, the initial values observed for obtaining a system can be continuously estimated by OLSM. It has been found that if the autoregressive coefficient of the two predictors is relatively high and the number of observations of the time series is relatively small, then the performance of the classical first-differenced GMM estimator can be significantly improved. In this process the asymptotic variance relations indicate that the system GMM estimator may be considerably better efficient than the non-linear GMM estimator.

A crucial assumption for the validity of system GMM is that the instruments are exogenous. In order to be valid of system GMM estimates, the instrumental variables included in the model should be external in other words the over identifying restrictions should be valid. Due to the validity of this hypothesis, the consistency of the instrumental variables used in the model is frequently tested using with the Sargan test. In Roodman (2009) study, Hansen and Diff-Hansen tests can be used in addition to the Sargan test when the validity of the instrumental variables included in the model is tested. The study also showed that the Hansen test was more resistant than the Sargan test. In the Hansen test with the difference of the sargan test the validity of the instrumental variables (exogeneity) is tested at both level and GMM equation.

There are several reasons for choosing system GMM approach. First, fixed panel estimation omits dynamics causing dynamic panel estimation bias. Omitted dynamics means that such models are mis- 
specified, because they occur over the impacts of lagged dependent variable as a right-hand-side variable on dependent variable. Second, the endogeneity problem which occurs when the independent variable is interacted with the error term in a regression model can be dealt with easier in dynamic panel data models than in the fixed models. Third, in multivariable dynamic panel models the sysGMM estimator is seen to act stronger than the differenced-GMM (DIF-GMM) produced by Arellano and Bond (1991). The sys-GMM estimation is further acceptable when variables are "random walk" or strong to be random walk variables because DIF-GMM estimator can suffer from a nervous instruments problem in that process. Fourth, sys-GMM is a better rational estimator when series are continuous, in which the lagged levels of variables are poor instruments for consequent alterations and there is an immediate reduction in the fixed sample tendency owing to the exploitation of additional moment conditions. Apart from the reasons marked out above, if one tries with an unbalanced panel data thus it is greater to avoid DIF-GMM estimation, which provides a lack of magnifying gaps. Although our panel data is heavily balanced, we avoid running DIF-GMM estimation (Çoban and Topçu, 2013).

\section{Empirical findings}

The empirical test is implemented using system GMM estimator for the emerging countries. Two different dependent variables (re and retj) were used in models to measure renewable energy consumption in the study. System GMM panel estimation results of the re dependent variable for the emerging countries are explained in Table 5. Consistent with the most current literature, each specification subsists of a lagged value of renewable energy consumption, and current period banking and stock market variables. Nine models were constructed with each dependent variable and analysis was performed with a total of eighteen models for the emerging countries. Each banking and stock market variables performed individually in all models in order to examine the relationship between renewable energy consumption and financial development.

Table 5 - System GMM panel estimation regression results for re

\begin{tabular}{|c|c|c|c|c|c|c|c|c|c|}
\hline Değişken & Model 1 & Model 2 & Model 3 & Model 4 & Model 5 & Model 6 & Model 7 & Model 8 & Model 9 \\
\hline re (-1) & $\begin{array}{r}0.981^{* * * *} \\
(40.96) \\
\end{array}$ & $\begin{array}{c}0.973^{* * * *} \\
(44.62)\end{array}$ & $\begin{array}{c}0.969^{* * *} \\
(46.92) \\
\end{array}$ & $\begin{array}{r}0.975^{* * *} \\
(43.94)\end{array}$ & $\begin{array}{r}0.968^{* * *} \\
(48.71) \\
\end{array}$ & $\begin{array}{c}0.965^{* * *} \\
(47.83) \\
\end{array}$ & $\begin{array}{c}0.981^{* * * *} \\
(39.11) \\
\end{array}$ & $\begin{array}{c}0.975^{* * *} \\
(41.47)\end{array}$ & $\begin{array}{r}0.969^{* * *} \\
(46.49)\end{array}$ \\
\hline dbagdp & $\begin{array}{c}0.073^{*} \\
(2.04) \\
\end{array}$ & $\begin{array}{r}0.082^{* *} \\
(2.14) \\
\end{array}$ & $\begin{array}{l}0.049 \\
(1.67) \\
\end{array}$ & & & & & & \\
\hline llgdp & & & & $\begin{array}{l}0.064 \\
(1.65) \\
\end{array}$ & $\begin{array}{c}0.073^{*} \\
(1.80)\end{array}$ & $\begin{array}{l}0.041 \\
(1.27) \\
\end{array}$ & & & \\
\hline pcrdbgdp & & & & & & & $\begin{array}{c}0.047^{*} \\
(1.84) \\
\end{array}$ & $\begin{array}{c}0.052^{*} \\
(1.94) \\
\end{array}$ & $\begin{array}{l}0.034 \\
(1.61) \\
\end{array}$ \\
\hline stmktcap & $\begin{array}{l}-0.017 \\
(-1.79)\end{array}$ & & & $\begin{array}{r}-0.016 \\
(-1.79)\end{array}$ & & & $\begin{array}{r}-0.013 \\
(-1.65)\end{array}$ & & \\
\hline stvaltraded & & -0.017 & & & -0.015 & & & -0.013 & \\
\hline
\end{tabular}


Table 5 reports the expected coefficient on the lagged renewable energy consumption variable is

There are some post estimation tests in the lower of panel table 5. AR(1) and AR(2) are Arellano and renewable energy consumption in 1 year is massively affected by renewable energy consumption in the previous year. The expected coefficient on banking variables (dbagdp, llgdp and pcrdbgdp) is positive in each of the nine models but only dbagdp variable is statistically significant at the $5 \%$ level in model 2. These results are significant in establishing that financial development does not impact renewable energy consumption in emerging economies when financial development is determined employing banking variables except model 2. The calculated coefficients on stock market variables (stmktcap, stvaltraded and stturnover) are negative in each of the nine models and statistically not considerable at the 5\% level in all models. These results show that financial development does not impact renewable energy consumption in emerging economies when financial development is measured employing stock market variables. Bond (1991) studies for first-order and second-order autocorrelation in the first differenced errors. When the regression errors are independent and evenly dispersed, the first differenced errors are by design auto-correlated. Results of AR(1) and AR(2) tests emphasize the effectiveness of the model specification for emerging countries. Sargan/Hansen statistics can also be used to test the validity of subsets of overidentifying restrictions (instruments). A rejection from this test indicates that model or instruments may be miss-specified. These tests confirm the validity of instruments in the all models. These post estimation results indicate that the dynamic panel model is a fairly respectable specification for renewable energy consumption in emerging economies. The strongest results indicate that there is no relationship between financial development and renewable energy consumption in emerging 
countries when financial development is measured employing both banking and stock market variables. Chang et al. (2009) research has findings supporting these findings because it suggests that countries described by low-economic growth countries tend to be insensitive to energy price shapes when they take place to their level of renewable energy. Also for supporting our paper, Ali et al. (2018) study shows that there was no causality between renewable energy consumption and financial development in upper middle income countries whose are similar countries to our study.

In addition to these results, Table 6 reports sys-GMM panel estimation results of the retj as a dependent variable for the emerging countries. An alikeness of the empirical results in Table 6 with Table 5 point out that for a definite model handed out, the empirical assessments are quite similar. In nine models indicate that lagged value of renewable energy consumption in terajoule (retj) has statistically significant and positive impact on renewable energy consumption in the previous year. While none of the banking variables were statistically significant for each model; for stock market variables, only the coefficient of the stmktcap variable is significant and positive in each model. The coefficient of the stmktcap variable is positive, so that it can be said that the financial development increases renewable energy consumption if it is measured by stock market capitalization. However, the strength of this relationship can be said weak because such a relationship cannot be found in the other two stock market variables and cannot be achieved similar findings in previous analysis of dependent variable (re).

Table 6 - System GMM panel estimation regression results for retj

\begin{tabular}{|c|c|c|c|c|c|c|c|c|c|}
\hline Değişken & Model 1 & Model 2 & Model 3 & Model 4 & Model 5 & Model 6 & Model 7 & Model 8 & Model 9 \\
\hline $\operatorname{retj}(-1)$ & $\begin{array}{c}0.985^{* * *} \\
(102.31)\end{array}$ & $\begin{array}{c}0.991^{* * *} \\
(122.08)\end{array}$ & $\begin{array}{c}0.984^{* * *} \\
(97.29)\end{array}$ & $\begin{array}{l}0.978^{* * *} \\
(92.05)\end{array}$ & $\begin{array}{c}0.986^{* * *} \\
(112.29)\end{array}$ & $\begin{array}{c}0.977^{* * *} \\
(91.43)\end{array}$ & $\begin{array}{r}0.985^{* * *} \\
(99.27)\end{array}$ & $\begin{array}{c}0.992^{* * *} \\
(126.14)\end{array}$ & $\begin{array}{l}0.987^{* * *} \\
(106.18)\end{array}$ \\
\hline dbagdp & \begin{tabular}{r|}
0.001 \\
$(0.05)$
\end{tabular} & $\begin{array}{r}0.02 \\
(0.65)\end{array}$ & \begin{tabular}{r|}
0.030 \\
$(1.19)$
\end{tabular} & & & & & & \\
\hline llgdp & & & & $\begin{array}{l}-0.027 \\
(-1.26)\end{array}$ & $\begin{array}{l}-0.008 \\
(-0.30)\end{array}$ & $\begin{array}{r}0.016 \\
(0.66) \\
\end{array}$ & & & \\
\hline pcrdbgdp & & & & & & & $\begin{array}{l}-0.003 \\
(-0.02) \\
\end{array}$ & $\begin{array}{l}0.010 \\
(0.49) \\
\end{array}$ & $\begin{array}{l}0.020 \\
(1.10) \\
\end{array}$ \\
\hline stmktcap & $\begin{array}{r}0.141^{* * *} \\
(2.94) \\
\end{array}$ & & & $\begin{array}{r}0.018^{* * *} \\
(3.91)\end{array}$ & & & $\begin{array}{r}0.014^{* *} \\
(2.74)\end{array}$ & & \\
\hline stvaltraded & & $\begin{array}{l}0.003 \\
(0.63) \\
\end{array}$ & & & $\begin{array}{l}0.086 \\
(1.93)\end{array}$ & & & $\begin{array}{l}0.005 \\
(0.94)\end{array}$ & \\
\hline stturnover & & & \begin{tabular}{|c|}
-0.012 \\
$(-0.97)$ \\
\end{tabular} & & & \begin{tabular}{|l|}
-0.011 \\
$(-0.91)$ \\
\end{tabular} & & & $\begin{array}{l}-0.118 \\
(-0.94) \\
\end{array}$ \\
\hline AR1 & $\begin{array}{r}-2.55 \\
{[0.011]} \\
\end{array}$ & $\begin{array}{r}-2.72 \\
{[0.006]} \\
\end{array}$ & $\begin{array}{r}-2.55 \\
{[0.011]}\end{array}$ & $\begin{array}{r}-2.54 \\
{[0.011]} \\
\end{array}$ & $\begin{array}{r}-2.71 \\
{[0.007]} \\
\end{array}$ & $\begin{array}{r}-2.53 \\
{[0.011]} \\
\end{array}$ & $\begin{array}{r}-2.55 \\
{[0.011]} \\
\end{array}$ & $\begin{array}{r}-2.71 \\
{[0.007]} \\
\end{array}$ & $\begin{array}{r}-2.55 \\
{[0.011]} \\
\end{array}$ \\
\hline AR2 & $\begin{array}{r}0.37 \\
{[0.710]} \\
\end{array}$ & $\begin{array}{r}-0.80 \\
{[0.424]} \\
\end{array}$ & $\begin{array}{r}0.24 \\
{[0.809]} \\
\end{array}$ & $\begin{array}{r}0.26 \\
{[0.792]} \\
\end{array}$ & $\begin{array}{r}-0.82 \\
{[0.410]} \\
\end{array}$ & $\begin{array}{r}0.16 \\
{[0.877]} \\
\end{array}$ & $\begin{array}{r}0.37 \\
{[0.712]} \\
\end{array}$ & $\begin{array}{r}-0.80 \\
{[0.422]} \\
\end{array}$ & $\begin{array}{r}0.26 \\
{[0.795]} \\
\end{array}$ \\
\hline $\begin{array}{l}\text { Sargan } \\
\text { Test }\end{array}$ & $\begin{array}{c}301.76 \\
{[0.621]}\end{array}$ & $\begin{array}{r}300.90 \\
{[0.664]}\end{array}$ & $\begin{array}{r}300.98 \\
{[0.633]}\end{array}$ & $\begin{array}{c}300.33 \\
{[0.565]}\end{array}$ & $\begin{array}{r}297.85 \\
{[0.635]}\end{array}$ & $\begin{array}{c}303.24 \\
{[0.518]}\end{array}$ & $\begin{array}{c}301.82 \\
{[0.620]}\end{array}$ & $\begin{array}{r}300.68 \\
{[0.667]}\end{array}$ & $\begin{array}{c}301.29 \\
{[0.628]}\end{array}$ \\
\hline Hansen & 16.62 & 17.73 & 17.29 & 13.19 & 14.73 & 19.42 & 17.01 & 17.30 & 18.43 \\
\hline
\end{tabular}


$p<0.01^{* * *}, p<0.05^{* *}, p<0.10^{*}$

Robust $t$ statistics reported beside determined coefficients. The regression coefficients are determined utilizing the Arellano and Bover (1995) and Blundell and Bond (1998) system GMM estimation procedure. Following the suggestions of Roodman (2009), estimation uses the xtabond2 command in Stata13.

$A R(1)$ and $A R(2)$ are Arellano and Bond (1991) tests for autocorrelation in differences.

Sargan is a test (Sargan (1958)) for overidentification restrictions. Hansen is a test (Hansen (1982)) for overidentification restrictions. $p$ values for these tests shown in square parenthesis.

According to post estimation tests in the lower of panel table 6, the findings of the AR(2) tests show no evidence of autocorrelation at conventional levels of significance. Also Sargan and Hansen tests

454 indicate that none of the models show evidence of miss-specification at the $5 \%$. The strongest 455 evidence supporting the hypothesis that there is relationship between financial development and 456 renewable energy consumption comes from only model 1, model 4 and model 7 . It is thought that the 457 reason of weak relationship between financial development and renewable energy consumption is the 458 banking system of emerging countries is less efficient than developed countries in terms of fulfilling 459 the function. These conclusions are coherent with Chang et al. (2009) that countries identified by higheconomic growth are able to react to high energy prices with rises in renewable energy usage, while countries described by low-economic growth countries manage to be insensitive to energy price variations when they come to their level of renewable energy. Also, Payne (2009) indicates that the absence of Granger-causality between renewable or non-renewable energy consumption and real GDP and in this study there is no relation between financial development and renewable energy consumption in emerging countries. Besides, for reinforcing our study, Anton and Nucu (2020) research reveals that capital market development does not affect renewable energy consumption in the new EU Member States. 


\section{Conclusion and Policy Implications}

469 Energy is of great importance for countries to maintain their economic development goals and increase their social welfare levels. A great number of regulations have been made by governmental authorities around the world to increase energy efficiency in the building, transportation and industrial sectors at

472 the regional, national and local level. The energy researches have mostly, very little to suggest about 473 the link between financial development and renewable energy consumption. The empirical methodology uses newly developed generalized method of moment's systems to establish for potential endogeneity between renewable energy consumption and financial development.

476 System GMM panel estimation results of the renewable energy consumption dependent variable for 477 the emerging countries show that there is no relationship between financial development and 478 renewable energy consumption in emerging countries when financial development is measured 479 employing both banking and stock market variables. On the other hand, only the ratio of deposit money bank assets to GDP (dbagdp) variable, which is one of the banking variables, was found statistically significant in one model. These results are important in establishing that increases in financial development, measured using both banking variables and stock market variables, do not increase renewable energy consumption in emerging economies.

In addition, the analysis was performed with the renewable energy consumption (TJ) which is second dependent variable. When the analysis findings are evaluated, only the ratio of market capitalization to GDP (stmktcap) was found significant and positive in every model participated in. No significant relationship was found for any of banking and the other stock market variables. The coefficient of the stmktcap variable is positive, so that it can be said that the financial development increases renewable energy consumption if it is measured by stock market capitalization. According to these findings, it is recommended to market makers that increasing stock market capitalization and the ratio of deposit money bank assets to GDP in order to increase renewable energy investments in emerging countries. 


\section{Ethical Approval}

494 We as an author Oğuz SAYGIN and Ömer İSKENDEROĞLU consciously assure that for the 495 manuscript "The Nexus Between Financial Development and Renewable Energy Consumption: A 496 Review For Emerging Countries" the following is fulfilled:

497 1) The paper reflects the authors' own research and analysis in a truthful and complete manner.

498 2) All authors have been personally and actively involved in substantial work leading to the paper, 499 and will take public responsibility for its content.

\section{Consent to Participate}

501 Not applicable

\section{Consent to Publish}

503 Not applicable

\section{Authors Contributions}

505 Conceptualization: Oguz Saygin

506 Data curation: Oguz Saygin, Omer Iskenderoglu

507 Formal analysis: Oguz Saygin.

508 Investigation: Oguz Saygin.

509 Methodology: Oguz Saygin, Omer Iskenderoglu

510 Supervision: Oguz Saygin, Omer Iskenderoglu

511 Validation: Oguz Saygin, Omer Iskenderoglu

512 Visualization: Oguz Saygin.

513 Writing - Original Draft: Oguz Saygin, Omer Iskenderoglu

514 Writing - Review \& Editing: Oguz Saygin, Omer Iskenderoglu

515

\section{$516 \quad$ Funding}

517 No funding was received to assist with the preparation of this manuscript.

\section{Competing Interests}

519 We wish to confirm that there are no known conflicts of interest associated with this publication The

520 authors alone are responsible for the content and writing of this article.

\section{Availability of data and materials}

522 The datasets are analyzed during the current study are available from World Bank World Development

523 Indicators (WDI) and Global Financial Development Database (www.datacatalog.worldbank.org). 


\section{References}

Alberini, A., Cropper, M., Fu, T.T., Krupnick, A., Liu, J.T., Shaw, D. and Harrington, W., (1997). Valuing Health Effects of Air Pollution in Developing Countries: The Case of Taiwan. Journal of Environmental Economics and Management. 34 (2). 107-126. https://doi.org/10.1006/jeem.1997.1007.

Ali, Q., Khan, M.T.I., Khan, M.N.I., (2018). Dynamics between financial development, tourism, sanitation, renewable energy, trade and total reserves in 19 Asia cooperation dialogue members. J. Clean. Prod. 2018 (179), 114-131. https://doi.org/10.1016/j.jclepro.2018.01.066

Ampornpisit, M., (2011). Financial Development and Economic Development: The Roles of the Thai Specialized Financial Institutions and Economic Development. Ph. D. Dissertation, Claremont Graduate University, USA.

Anton, S. G., Nucu A.E.A., (2020). The effect of financial development on renewable energy consumption. A panel data approach. Renewable Energy. 147. 330-338. https://doi.org/10.1016/j.renene.2019.09.005

Apergis, N., Payne, J.E., (2010a). Renewable energy consumption and growth in Eurasia. Energy Econ. 32 (6), 1392-1397. https://doi.org/10.1016/j.eneco.2010.06.001

Apergis, N., Payne, J.E., (2010b). Renewable energy consumption and economic growth: evidence from a panel of OECD countries. Energy Policy 38 (1), 656-660. https://doi.org/10.1016/j.enpol.2009.09.002

Apergis, N., Payne, J.E., (2011). The renewable energy consumption-growth nexus in Central America. Appl. Energy 88 (1), 343-347. https://doi.org/10.1016/j.apenergy.2010.07.013

Apergis, N., Payne, J.E., (2012). Renewable and non-renewable energy consumption-growth nexus: evidence from a panel error correction model. Energy Econ. 34 (3), 733-738. https://doi.org/10.1016/j.eneco.2011.04.007

Arellano, M., Bond S. R. (1991). Some tests of specification for panel data: Monte Carlo evidence and an application to employment equations. Review of Economic Studies. 58, 277-97. https://doi.org/10.2307/2297968

Arellano, M., Bover O. (1995). Another look at the instrumental variable estimation of errorcomponents models. Journal of Econometrics. 68, 29-51. https://doi.org/10.1016/03044076(94)01642-D 
Baltagi, B. H. (2005). Econometric analysis of panel data. Third edition. England: John Wiley.

Beck, T., Demirgüç-Kunt, A., Levine, R. (2000). A new database on the structure and development of financial sector. World Bank Policy Research Working Paper, June, 1-95. https://doi.org/10.1093/wber/14.3.597

Bobinaite, V., Juozapaviciene, A., Konstantinaviciute, I. (2011). Assessment of causality relationship between renewable energy consumption and economic growth in Lithuania. Engineering Economics. 22(5), 510-518. https://doi.org/10.5755/j01.ee.22.5.969

Blundell, R., Bond S. (1998). Initial conditions and moment restrictions in dynamic panel data models. Journal of Econometrics. 87, 115-143. https://doi.org/10.1016/S0304-4076(98)00009-8

Brunnschweiler, C.N., (2010). Finance for renewable energy: an empirical analysis of developing and transition economies. Environ. Dev. Econ. $15 \quad$ (3), 241-274. https://doi.org/10.1017/S1355770X1000001X

Chang, T. H., Huang, C.M., Lee, M.C., (2009). Threshold effect of the economic growth rate on the renewable energy development from a change in energy price:Evidence from OECD countries. Energy Policy. 37, 5796-5802. https://doi:10.1016/j.enpol.2009.08.049

Ciftci, D.D., Soytas, U., Nazlioglu, S., (2020). Financial development and energy consumption in emerging markets: Smooth structural shifts and causal linkages. Energy Economics. 87, 1-17. https://doi.org/10.1016/j.eneco.2020.104729

Çakar, M. C., Firik, Ü. B., Kurban, M., (2009). Use Application of Renewable Energy Sources and Transport System, V. In V. Renewable Energy Resources Symposium Proceedings Book. 237241.

Çoban, S., Topcu, M., (2013). The nexus between financial development and energy consumption in the EU: a dynamic panel data analysis. Energy Economics. 39, 81-88. https://doi.org/10.1016/j.eneco.2013.04.001

EIA, (2010). The International Energy Outlook 2010, Web: www.eia.gov/forecasts/ieo/pdf/0484(2010).pdf

Eren, B.M., Taspinar N., Gokmenoglu K.K. (2019). The impact of financial development and economic growth on renewable energy consumption: Empirical analysis of India. Science of the Total Environment. 663, 189-197. https://doi.org/10.1016/j.scitotenv.2019.01.323 
Fang, Y., (2011). Economic welfare impacts from renewable energy consumption: The China experience. Renewable and Sustainable Energy Reviews. 15, 5120-5128. . https://doi.org/10.1016/j.rser.2011.07.044

Hassine, M.B., Harrathi, N., (2017). The causal links between economic growth, renewable energy, financial development and foreign trade in Gulf Cooperation Council countries. Int. J. Energy $\begin{array}{lllll}\text { Econ. } & \text { Policy } & \text { (2), }\end{array}$ https://www.econjournals.com/index.php/ijeep/article/view/3976/2657

Jebli, M.B., Youssef, S.B., Apergis, N., (2014). The Dynamic Linkage between CO2 Emissions, Economic Growth, Renewable Energy Consumption, Number of Tourist Arrivals and Trade. MPRA Paper No. 57261, Munich Personal RePEc Archive. https://ideas.repec.org/p/pra/mprapa/57261.html

Ji Q., Zhang D., (2019). How much does financial development contribute to renewable energy growth and upgrading of energy structure in China? Energy Policy. 128, 114-124. https://doi.org/10.1016/j.enpol.2018.12.047

Khan, M.T.I., Yaseen, M.R., Ali, Q., (2019). Nexus between financial development, tourism, renewable energy, and greenhouse gas emission in high-income countries: A continent-wise analysis. Energy Economics, 83, 293-310. https://doi.org/10.1016/j.eneco.2019.07.018

King, R. G., Levine R. (1993). Finance and Growth: Schumpeter Might Be Right. Quarterly Journal of Economics, 108(3), 717-737. https://doi.org/10.2307/2118406

Levine, R., (2005). Finance And Growth: Theory And Evidence. Handbook of economic growth. 1, 865-934.

Payne, J.E., (2009). On the dynamics of energy consumption and output in the US. Appl. Energy 86 (4), 575-577. https://doi.org/10.1016/j.apenergy.2008.07.003

REN21, (2014). 10 Years Of Renewable Energy Progress, Paris.

REN 21, (2017). Renewables 2017 global status report. Paris. Retrieved from. http://www. ren21.net/wp-content/uploads/2017/06/17-8399_GSR_2017_Full_Report_0621_Opt.pdf.

Roodman, D., (2009). How to do xtabond2: An introduction to difference and system GMM in Stata. The Stata Journal. 1, 86-136. https://doi.org/10.1177\%2F1536867X0900900106

Sadorsky, P., (2010). The impact of financial development on energy consumption in developed economies. Energy Policy 38 (5), 2528-2535. https://doi.org/10.1016/j.enpol.2009.12.048 
Sadorsky, P., (2011). Financial development and energy consumption in Central and Eastern European $\begin{array}{lllll}\text { frontier economies. } & \text { Energy } & \text { Policy } & 39 & \text { (2), 999-1006. }\end{array}$ https://doi.org/10.1016/j.enpol.2010.11.034

Sargan, J. D., (1958). The estimation of economic relationships using instrumental variables. Econometrica 26: 393-415. https://www.jstor.org/stable/1907619

Savolainen, K. M., Svento, R., (2013). Promotion of Market Access for Renewable Energy in the Nordic Power Markets. Environ Resource Econ 54, 549-569. https://doi.org/10.1007/s10640012-9605-z.

Shahbaz, M., Khan, S., Tahir, M.I., (2013). The dynamic links between energy consumption, economic growth, financial development and trade in China: fresh evidence from multivariate framework analysis. Energy Econ. 40, 8-21. https://doi.org/10.1016/j.eneco.2013.06.006

Stiglitz, J., Weiss A. (1981). Credit Rationing in Markets with Imperfect Information. American Economic Review, June, 393-410.

Tugcu, C.T., Ozturk, I., Aslan, A., (2012). Renewable and non-renewable energy consumption and economic growth relationship revisited: evidence fromG7 countries. Energy Econ. 34 (6), 19421950. https://doi.org/10.1016/j.eneco.2012.08.021

World Bank, (2017a). Global financial development database. Retrieved from. https://data.worldbank.org/data-catalog/global-financial-development.

World Bank, (2017b). World development indicators. Retrieved from. http://databank.worldbank.org.

Zhang, Y., Fan, J., Chang, H., (2011). Impact of China's Stock Market Development on Energy Consumption: An Empirical Analysis. Energy Procedia. 5, 1927-1931. . https://doi.org/10.1016/j.egypro.2011.03.331 